Research Article

\title{
The National Higher Education Fund Corporation Loan Helps the Malaysian Students to Solve Education Problems
}

\author{
Gunasegaran Karuppannan ${ }^{1}$, Buvaneswary Balasubramaniam ${ }^{2}$, Abu Bakar Mohd Sheikh ${ }^{3}$ \& Syed \\ Lamsah Syed Chear ${ }^{4}$ \\ ${ }^{1}$ Deputy Dean, Centre For Graduate Studies, Universiti Selangor, Malaysia. \\ ${ }^{2}$ Senior Assistant, Special Education, Secondary School, Malaysia. \\ ${ }^{3}$ Head of Doctorate Program, Faculty of Education \& Social Scinces, Universiti Selangor, Malaysia. \\ ${ }^{4}$ Head of Practicum Unit, Faculty of Education \& Social Scinces, Universiti Selangor \\ Correspondence : Assoc. Prof. Dr Gunasegaran Karuppannan, Shah Alam Campus, Jalan Zirkon A 7/A, \\ Seksyen 7, 40000 Shah Alam, Selangor, Malaysia.
}

\begin{abstract}
Traditionally, access of primary and secondary education has been easier for most people in Malaysia. The challenge has always arisen when it comes to tertiary education. Most people are unable to fund themselves or through their families to continue their studies in higher education institutions. In Malaysia, a key to help the finance tertiary education is by the National Higher Education Fund Corporation. This study seeks to assess the effectiveness of the National Higher Education Fund Corporation loan in improving the access to education, more particularly tertiary education. A qualitative study was conducted to find whether the National Higher Education Fund Corporation loan really helps the Malaysian students to solve their financial problem in tertiary education. The study shows that many parents are saying that the National Higher Education Fund Corporation loan is a real help to reduce their financial problem. At the same time there are also parents reject the National Higher Education Fund Corporation loan because they don't want to burden their children in paying back the loan.
\end{abstract}

Key words: tertiary education, financial problem, parents, effectiveness, qualitative

\section{Introduction}

There was an increase in the level of appreciation of tertiary education globally in this era. More people began to see the importance of acquiring tertiary education. In Malaysia, in 1997 the National Higher Education Fund Corporation was established to fund for the tertiary education in public and private sector. The key functions of this body were established with the enactment of National Higher Education Fund Corporation loan Act of 1997. The National Higher Education Fund Corporation loan surely had its successes story, at the same time it had its fair share of challenges.

There are not many researches available on the subject of the National Higher Education Fund Corporation loan's contributions to the students in Malaysia. The Section 9 of the National Higher Education Fund Corporation loan Act sets out the functions of the corporation and this is being chief of the provision and grant of educational loans and administration of these loans. The administration of the National Higher Education Fund Corporation loan includes activities like fund raising, disbursement, monitoring and collection of repayments of the borrowers who are the $100 \%$ of the student group.

\section{Statement of Problem}

The National Higher Education Fund Corporation loan Act of 1997 is the primarily legislation act of the student educational fund in Malaysia. This is related to the provision of funds to support students who wish to pursue further education in Malaysia. 
In fact, with the Establishment and existence of National Higher Education Fund Corporation loan fund, many students benefit from it. However, its scope is limited mostly due to the lack of resources. The amount of millions has been given out to it's borrowers ever since it has been established but there is still a perception that the amount being fund to students are not sufficient enough to cater the needs of the students in higher education institutes. The interest rate of National Higher Education Fund Corporation loan is on the lowest side compared to other conventional loans. Despite this, the National Higher Education Fund Corporation loan is also facing non repayment issues by it's borrowers. Based on the survey conducted, there is a general feeling among parents and guardians on this loan. They say even though the loans are helpful, but the National Higher Education Fund Corporation loan could be a future liability for the children. So some of the parents discourage their children from applying for the National Higher Education Fund Corporation loan So in this study we would like to find out whether the National Higher Education Fund Corporation loan helps the Malaysian students to solve education problems..

\section{Objectives of the study}

In view of the above-mentioned and the problem made clear in the earlier sections, the overall and main objective of this study is to evaluate how the National Higher Education Fund Corporation loan has contributed to addressing challenges related to education and particularly access to higher education. In seeking to achieve this, there are additional and more specific objectives that the study seeks to realize. These include the following:

a. To determine whether there is an increase in access to higher education as a result of the provision of the National Higher Education Fund Corporation loan disbursements in Malaysia.

b. To establish whether the amounts disbursed have been sufficient in meeting the needs of the students.

\section{Literature Review}

Many researchers indicated the increase of education fee unavoidable but it does not affect the students enrollment in tertiary level due to the availability of student loans. In Singapore, the 1988 university tuition fee rises but it was accompanied by subsidized loans by government equivalent to about half the value of the new increased tuition fees. Where else, the Australian loan scheme was introduced conjunction the with the imposition of university tuition fees in 1989. In the early 1980s, The amount of the tuition fee increased in Chile but accompanied by the introduction of student loans administered by the universities (Ziderman , 2013)

There is a little amount of empirical research that has been conducted on the issue of the resourcefulness of the National Higher Education Fund Corporation loan in helping students address their education challenges. Available research points to how much people do not appreciate the significance of the National Higher Education Fund Corporation loan. This is best demonstrated by the calls for disbandment of the fund and the lack of political goodwill to ensure that adequate resources are allocated to the fund (The Edge Markets, 2018). Members of the political class call for the abolishment of the fund and instead the introduction of free tertiary education, something that is difficult to achieve.

There are calls for reforms to ensure that the National Higher Education Fund Corporation loan is more friendly and sensitive to the circumstances of the borrowers. Formally, there is no discrimination with regards to eligibility. However, when it comes to real life practice, the allocation of funds is according to a quota policy that is based on the races of applicants (Das, 2014). By introducing such reforms that address these issues, more students from the low-income families will be able to access the loans and thereby afford tertiary education (Das, 2014).

Upon joining tertiary institutions like universities and colleges, students start to experience a lot of financial pressure. This pressure is related to the costs of sustaining their stay in these institutions (Nyoto, et al, 2021). The National Higher Education Fund Corporation loan educational loans have helped students to be able to get through these times and challenges by affording them resources to fund their tuition and even the 
additional expenses related with their education (Omran, 2016). For instance, some are able to afford such necessities as personal laptops and books which aid in their education.

\section{Methodology}

This research was conducted as qualitative method. The study utilizes mostly online research and materials, numerous books, scholarly articles, journals, publications and media statements. Then the additional data from scholarly journal and publications as well as other online sources also helpful in the evaluation of the effectiveness of the fund in addressing student problems as well as the arising issues such as the inadequate funding that the fund gets as compared to the demand.

There were two respondents who gave insightful data that is crucial to this research. They are:

I. Ms. Sharmila Krishnan who is an Executive in charge of Student Loan Programmes in AIMST University.

II. Ms. Marlina bt Abdul Malik who is the officer for Empowerment, Development of SocioEconomic and Caring Government in Selangor State Government .

The interviews also include the following groups:

a) 10 selected parents whose children are currently admitted in tertiary institutions within the country and who have borrowed from the National Higher Education Fund Corporation loan.

b) 10 parents of students currently admitted in tertiary institutions within the country who have not borrowed from the National Higher Education Fund Corporation loan.

The evaluation of this interview played a key role in enabling the assessment of the impact that the National Higher Education Fund Corporation loan has had, especially in terms of addressing the challenges that students face.

\section{Results of the Study}

In a 2018 report, Higher Education Minister observed that the government had funded ninety percent (90\%) of the costs incurred in public tertiary institution for most people. The remaining $10 \%$ had also been funded indirectly by affording them educational loans through the National Higher Education Fund Corporation loan (The Edge Markets, 2018). This is an address in which the Minister was critical of the lack of appreciation by most people of how much the fund had come to their aid.

There is no doubt that the cost of accessing higher education is unaffordable for most people. the National Higher Education Fund Corporation loan allow students to be able to pay the costs either fully or partially. It also enables them to cover such costs that are associated with the higher learning, for instance the money that is spent on accommodation and learning materials. Some even said that the loans offered by the National Higher Education Fund Corporation loan are regarded as a lifeline. (Sani, 2020)

By providing educations loans, especially to students who come from lower-income backgrounds, the National Higher Education Fund Corporation loan contributes to the socioeconomic growth of the country. This is because upon attaining higher education, the students are exposed to more and greater opportunities than they would have had without the higher education. consequently, they are able to improve their lives as well as those of their families. This in turns contributes to the socioeconomic growth of the country as the living standards of more people to get better.

The contribution of the National Higher Education Fund Corporation loan is getting bigger and bigger due to the increase in the enrolment of students in tertiary institutions. As at 2011, the number of students in private tertiary institutions who received educational loans from the fund were $40 \%$ of the total recipients. As for the numbers, 2011 had 88,834 recipients are private tertiary institutions. This was a huge increase from the 179 recipients in 1997 when the fund and loan programme was first established. It is also a substantial increase in comparison to the 8,286 recipients in 2000, and 45,704 in 2005. (Ming.,et all,2016). 
More than half of the parents who were interviewed were (80\%) said PTPN is very helpful but not enough to cover cost thus they have to find other source of fund to support their children. About $50 \%$ of the students who took part in the research indicated that they came from rural places. Most of them were in the senior years (third, fourth or fifth) of the programmes they are pursuing.

To get an idea as to their backgrounds and to know the kind of environment in which they were brought up in and lived in, the respondents were all asked to give feedback as to where they originated from. Most of them indicated as having originated from rural areas.

For the parents who have taken the educational loan for their children's education were asked to indicate on a scale of 1 to 4 whether the loans had helped them solve their problems. 1 is "Strongly Disagree", 2 is "Disagree", 3 is "Agree", and 4 is "Strongly Agree". The respondents were also asked to briefly state their reasons for their choice.

The respondents were also asked as to whether they felt that the amounts offered were not inadequate in meeting their costs. From the data, a huge majority of them felt that the amounts disbursed to each was inadequate.

\section{Table 1}

\begin{tabular}{|l|c|l|l|c|}
\hline & $\begin{array}{l}1 \\
\text { Strongly Disagree }\end{array}$ & $\begin{array}{l}2 \\
\text { Disagree }\end{array}$ & $\begin{array}{l}3 \\
\text { Agree }\end{array}$ & $\begin{array}{l}4 \\
\text { Strongly Agree }\end{array}$ \\
\hline $\begin{array}{l}\text { 1.The PTPTN loans have helped you } \\
\text { solve your child's educational problem }\end{array}$ & 0 & 2 & 4 & 4 \\
\hline $\begin{array}{l}\text { 2. The amount given to your child were } \\
\text { given as PTPTN loan is inadequate and } \\
\text { does not meet all your financial needs at } \\
\text { school }\end{array}$ & 1 & 2 & 4 & 3 \\
\hline
\end{tabular}

For the respondent whose children did not take the National Higher Education Fund Corporation loan the questions were also asked, They regret because their child is not a borrower of the National Higher Education Fund Corporation loan and some says that the National Higher Education Fund Corporation loan is a burden for their child in the future. If they were asked to indicate if 1 Strongly Disagree, 2 Disagree, 3 Agree, 4 Strongly Agree.

\section{Table 2}

\begin{tabular}{|l|c|c|c|c|}
\hline & $\begin{array}{c}1 \\
\text { Strongly Disagree }\end{array}$ & $\begin{array}{c}2 \\
\text { Disagree }\end{array}$ & $\begin{array}{c}3 \\
\text { Agree }\end{array}$ & \begin{tabular}{c} 
Strongly Agree \\
\hline $\begin{array}{l}\text { 1. Regret because their child is not a } \\
\text { borrower of the National Higher } \\
\text { Education Fund Corporation loan }\end{array}$
\end{tabular} \\
\hline $\begin{array}{l}\text { 2. The National Higher Education } \\
\text { Fund Corporation loan is a burden for } \\
\text { their child in the future }\end{array}$ & 1 & 3 & 2 & 4 \\
\hline
\end{tabular}

About $60 \%$ of the respondent actually regretted for not encouraging their children to take the National Higher Education Fund Corporation loan once they entered in to college or University. About 2 respondents out of 10 said their child is not eligible for the National Higher Education Fund Corporation loan as parents have higher income status. More than half of the parents feel the National Higher Education Fund 
Corporation loan is a burden to their child as they have to pay back once start working. Most parents are also not aware that the National Higher Education Fund Corporation loan will turn into scholarship if the child get first class honored degree.

\section{Conclusion}

Compared to other educational loans in the market, there is no doubt that the National Higher Education Fund Corporation loan is the best offer for Malaysian students (Loans Street, 2019). Of utmost concern is the issue of inadequacy of the amounts in meeting the costs of the students. Similarly, there is need to improve on the disbursement particularly on the issue of partial grant of amounts applied for. The study also established that the administration of the fund has been effective hence the realization of the objectives of its establishment. For instance, the amount issued to students as education loan is not sufficient to cover all the basic requirements that their students require to effectively continue with their tertiary education programmes. This informs the recommendation of the study that there be an increase in the amount that the National Higher Education Fund Corporation loan offers in terms of student loans. However, for the Malaysian students the National Higher Education Fund Corporation loan was the best solution to overcome the higher education needs and overall, the National Higher Education Fund Corporation loan has contributed significantly in easing access to tertiary education.

\section{References}

1. Bakar, E. A., Masud, J., \& Jusoh, Z. M. (2006). Knowledge, attitude and perceptions of university students towards educational loans in Malaysia. Journal of family and economic issues, 27(4), 692-701.

2. Das, S. B. (2014). Malaysia's Socio-Economic Transformation. Flipside Digital Content Company Inc. Retrieved May 27, 2020, from https://books.google.co.ke/ books?Id=3hxqdwaaqbaj\&dq= PTPTN+helps+ students\&source $=$ gbs_navlinks_s

3. Loans Street. (2019, November 18). Is PTPTN The Best Study Loan Available For Malaysian Students Today? Retrieved May 28, 2020, from Loans Street: https://loanstreet.com.my/learning-centre/is-ptptn-thebest-study-loan-available-for-malaysian-students-today

4. Ming.O.K.,Yong.J.,Yen.C.K.,Ng.D.,(2016) The-Sustainability-of-the-PTPTN-Loan-Scheme, Dec 16, 2016.

5. New Straits Times (2020, April) https://www.nst.com.my/education/2020/04/580104/loans-lifeline- pursuingtertiary-education

6. Nyoto, Nicholas Renaldo, Gunasegaran Karuppannan \& Abul Bashar Bhuiyan \& Mokana Muthu Kumarasamy (2021). The Determinance Of The Financial Behavior Among Graduate Students In Indonesia. Australian Finance \& Banking Review, Volume 5 Number 1, 29-42. https://doi.org/10.46281/afbr.v5i1.1009

7. Omran, A. (2016). Identifying The Main Factors Affecting The Expenditure Of Students At Universiti Utara

8. Malaysia Using Ptptn. Universitatii Bucuresti. Analele. Seria Stiinte Economice si Administrative, 10, 33.

9. PTPTN, (2018, Mac 8) Siaran Media: https://www.ptptn.gov.my/images/fail/siaran_media/2018/dua dekad ptptn mengorak langkah.pdf

10. Sani, R. (2020, April 1). Loans: A lifeline for pursuing tertiary education. Retrieved May 27, 2020,

11. The Edge Markets. (2018, April 16). 'Many don't appreciate PTPTN for helping students'. Retrieved May 27, 2020, from The Edge Markets: https://www.theedgemarkets.com/article/many-dont-appreciate-ptptn-helpingstudents

12. Ziderman, A. (2013, June), Increasing Access to Higher Education Through Student Loans, Cesifo Dice Report. 